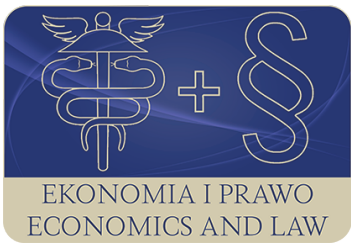

EKONOMIA I PRAWO. ECONOMICS AND LAW

Volume 17, Issue 4, December 2018

p-ISSN 1898-2255, e-ISSN 2392-1625

www.economicsandlaw.pl

ORIGINAL ARTICLE

received 02.01.2018; revised 25.06.2018; accepted 31.12.2018

Citation: Sypniewski, D. (2019). Competition restrictions by professional self-government. Ekonomia

i Prawo. Ecomomics and Law, 17(4): 405-415. doi:10.12775/EiP.2018.029.

\title{
Competition restrictions by professional self-government
}

\section{DOMINIK SYPNIEWSKI}

Warsaw University of Technology, Faculty of Administration and Social Science, Plac Politechniki 1, 00-661 Warszawa, Poland

$\square$ dominik.sypniewski@gmail.com

\begin{abstract}
Motivation: Professional self-government participates in the exercise of public authority. When supervising performance of public trust professions it may limit the competition and freedom of the profession, however it should be within the limits of the public inter-

est.

Aim: Purpose of this paper is to demonstrate that activities of professional self-government, which is an organization uniting and representing the interests of every person practicing a specified profession, may lead to restriction of competition. Thus professional self-government should be to subject to supervision of competition and consumer protection authorities.

Results: Professional self-government is classified as an association of entrepreneurs under Polish law and associations of undertakings under EU law. It is subject to competition rules, however pursuant to EU jurisprudence those rules do not apply to the exercising powers of a public authority. Under Polish law, normative acts issued by professional self-governments are controlled by the Supreme Court. When affecting competition, they are subject to a special administrative anti-trust regulation. An analysis of case law shows, that such control in necessary because professional self-governments attempt to influence to influence competition, in particular through a pricing policy.
\end{abstract}

Keywords: competition; professional self-government; association of entrepreneurs; 'state action' doctrine

JEL: K21 


\section{Introduction}

Can the activities of professional self-government, which is an organization uniting and representing the interests of every person practicing a specified profession, lead to restriction of competition? This problem was noticed ever since the early days of the classical economics when A. Smith (1776, p. 119), paid attention to the fact that 'people of the same trade seldom meet together, even for merriment and diversion, but the conversation ends in a conspiracy against the public, or in some contrivance to raise prices'. It is beyond any doubt that the authorities of professional self-government have economic incentives to undertake activities aimed at reducing a number of people practicing the specified profession, reducing possibilities of clients acquisition by new members of the professional self-government or maintaining high prices of services.

Professional self-government is an institution under public law where the membership - contrary to other association of entrepreneurs - is mandatory for every person practicing the specified profession. Legal grounds for establishment of a professional self-government are contained in Article 17.1 of the Polish Constitution (1997). Pursuant to Article 17.1 the legislator is entitled to establish professional self-governments representing persons practicing professions of public trust. The term 'profession of public trust' is typical for Polish legal system and while there are no explicit normative criteria, the term comprises law professions, medical professions (and related), technical professions (architect and construction engineer) and financial professions (tax advisor and statutory auditor).

Pursuant to Article 17.1 of the Polish Constitution (1997) professional self-government supervises a due performance of a profession within the public interest including its protection. For this purpose the authorities of the professional self-governments obtained not only numerous public duties of a regulatory character but also administrative power which entitled them to issue normative acts and settle disputes by the administrative acts.

Purpose of this paper is to present to what extent the activities of the professional self-governments pursued within the framework of performance of the public duties may negatively influence competition and to draw attention to legitimacy of the supervision over this activity by competition and consumer protection authorities.

\section{Literature review}

Even though the issues regarding professional self-government are subject of interests of the administrative law, there is still a small amount of studies devoted only to professional self-governments from the administrative law perspective. Apart from few monographs (Rączka, 2013; Tabernacka, 2007), publications regarding professional self-governments have mostly incidental 
character and are published as chapters in monographs or present legal regulations regarding only particular professional groups.

Under the competition law, issues regarding activities of professional self-government are mostly considered in view of legal definitions of an entrepreneur, association of entrepreneurs and agreements introduced by the Competition and Consumer Protection Act (hereinafter: the Competition Act, 2007), but also pursuant to the European Union competition rules. Special attention shall be drawn to publications of G. Materna $(2009,2014)$ and glossaries to the Competition Act.

Legal character of agreements restricting competition may have resolutions issued by professional self-government authorities which take a form of binding internal legal acts. The same consequences can have other acts of non-binding character which are addressed to the members and are most often called 'recommendations', 'advices', 'instructions' or 'suggestions'. They have not taken a form of a resolution or an act but there is still a possibility they may influence the competition (Skoczny, 2014, pp. 171-174).

\section{Methods}

In this paper the author applied a multidimensional attitude comprising in particular the elements of dogmatism, functionalism and comparative jurisprudence. On one hand the considerations are based on a language analysis of the normative acts from the area of the generally applicable provisions, competition law but also corporate law established by the authorities of professional self-government. On the other hand the article presents a process of application of law formed by court jurisprudence of the Court of Justice of the European Union (hereinafter: the Court of Justice), the General Court, the Constitutional Tribunal, the Supreme Court, and the Court of Competition and Consumer Protection (hereinafter: the Competition Court), but also by decisions of the President of the Office of the Competition and Consumer Protection (hereinafter: the President).

\section{Results}

\subsection{Professional self-government as a subject of competition law}

The essence of a competition policy is providing conditions for functioning of the competition what shall lead to growth in effectiveness of entrepreneurs, improvement of allocation of resources and increase of innovativeness. Purpose of the competition protection under public law is security of entrepreneurs' and consumers' interests against unfair practice aimed at restriction of competition. In connection with granting to professional self-governments public duties performed by administrative power, there arises a question whether the oper- 
ations taken pursuant to authorization of a legislator shall be subject to limitations arising from anti-monopoly provisions.

Pursuant to the European Union law, competition rules stipulated in the TFUE are addressed to undertakings or association of undertakings. Pursuant to the interpretation of the Court of Justice the concept of an undertaking encompasses every entity engaged in an economic activity, regardless of the legal status of the entity and the way in which it is financed (ECLI:EU:C:1991:161, I-01979, para 25). As any activity consisting of offering goods and services on a given market is an economic activity, the Court confirmed that members of the bar who provide clients with a legal assistance carry on an economic activity, so they are undertakings for the purpose of competition rules of the Treaty (ECLI:EU:C:2002:98, I-01577, para 48-49). A similar approach was applied to medical specialists (ECLI:EU:C:2000:428, I-06451, para 73-82).

It is much more complicated to determine whether a professional association can be treated as associations of undertakings within the meaning of Article 101 of the Treaty on the Functioning on the European Union (TFEU, 2012). Even though the member states shall refrain from activities facilitating professional self-governments restriction of competition (Article 4.3 of the Treaty on European Union (TUE, 2012)), jurisprudence of the Court adopted a state action doctrine. The doctrine allows national legislation and non-legislative actions of the state such as normative acts, individual administrative acts or actions of formally non-binding character to be a reason of behaviors violating competition, thus excluding possibility of application of Article 101 and Article 102 TFEU (2012) (Kowalik-Bańczyk, 2009, pp. 21-23). According to the case law of the Court, competition rules do not apply to the activity which is connected with exercising powers of a public authority. In the newer case law the Court claims that exercising power of public authority cannot afford absolute protection against any allegation of conduct in restriction of competition, since exercising power in a manifestly inappropriate way would in any event constitute a misuse of that power (ECLI:EU:T:2014:1049, para 207). Such an approach was adopted in other judgments. When drawing up the code of professional conduct, a professional association acts as a regulatory body of a profession. If the rules are binding on practitioners and the association is entitled to impose penalties in the event of non-compliance with the code, a professional association shall be regarded as an association of undertakings and the code as a decision under Article 101.1 TFEU (2012) (ECLI:EU:C:2013:489, para 42-48). If a professional association is legally required to organize a system of compulsory training for its members, adopting the rules for training, including a procedure for training giving an entitlement to training credits provided by bodies other than the association cannot affect the application of Article 101 TFEU (2012), where the infringement of which that professional association is accused, concerns a market on which it carries on an economic activity itself. (ECLI:EU:C:2013:127, para 59). 
Consequence of such a broad interpretation of the term 'undertaking' in the European Union law is the adoption by the Polish lawmaker a broad definition of the term 'entrepreneur' in the Competition Act (2007). In addition to entities performing economic activity as defined in the Freedom of Business Activity Act (2004), the status of an entrepreneur was given inter alia to any natural person who practices an occupation in his or her own name and for own account, or who within the framework of practicing this occupation carries on an economic activity. It also refers to the professional associations of such persons. Thus, it is unquestionable that public trust professions are subject to restrictions imposed by the Act, even if their status under the Freedom of Business Activity Act (2004) is not clear (Materna, 2009, p. 104).

Pursuant to Article 1.2 of the Competition Act (2007), the provisions of this act apply to associations of entrepreneurs. The scope of this term is broad and includes chambers, associations and other organizations associating the entrepreneurs or associations of associations. In spite of the recognition of the professional self-government as an association of entrepreneurs under the Polish law, it shall be emphasized that performing public duties by a professional self-government, even if it leads to restrictions of the economic freedom, does not have to restrict competition pursuant to anti-monopoly provisions of the European Union.

In this regard, it shall be considered that professional self-governments operating in Poland which represent persons exercising professions of public trust and supervise over proper performance of these professions are associations of entrepreneurs pursuant to the Competition Act (2007). Under the national regulations, broad jurisprudence of the Supreme Court and the Competition Court confirm the above mentioned statement and recognize authorities of the professional self-governments of advocates, doctors, veterinarians, pharmacists, notaries public and architects as associations of undertakings. In this regard, the authorities of professional self-governments are addressees of bans on applying practices which restrict competition and practices violating collective consumer interests.

\subsection{Activities of professional self-government}

Among functions exercised by a professional self-government from the perspective of an impact on the competition, the most important are functions relating to determining professional and deontological ethics and other norms connected with functioning of a corporation and profession. (Tabernacka 2007, p. 56). These functions are exercised by constituting the following normative acts (Tabernacka 2007, pp. 151-162):

- acts containing principles of professional and deontological ethics;

- acts containing non-deontological principals of pursuing a profession;

- acts regulating an organization and principles of functioning of the professional self-government bodies; 
- programs and strategies of professional self-government.

Normative acts of professional self-government are of the same nature as general acts which are addressed to any person practicing a particular public trust profession which are ex lege subject to a membership in a professional self-government. The above mentioned acts shape the organizational structure of a professional self-government, the way of performance of its statutory duties and the way of practicing the profession by its members so they are addressed exclusively to the entities subordinated to the self-government what leads to a conclusion that they can be defined as internal acts. Thus, it is possible to distinguish among them statutory acts stipulating the internal regime of a professional self-government, regulation acts stipulating the way of functioning of entities being members of the professional self-government and acts shaping the policy connected with exercising of public duties by the professional self-government.

The normative acts of professional self-government, regardless of their internal character, may have significant impact and effect in the internal sphere of the public administration. Professional self-government influences the availability of certain services, their price and quality and affects the competition inside the group by its operations such as: governing the rules for pursuing the profession, rules and programs regarding the legal apprenticeship, the way of enhancement of professional qualifications by the members of the self-government or imposing restrictions regarding advertising or issuing recommendations connected with fees. Moreover, professional self-governments have a fundamental instrument for influencing their members, namely possibility of pursuing disciplinary proceedings.

Analysis of the normative acts of the professional self-governments clearly shows that professional self-governments undertake operations violating anti-monopoly regulations. They most often take form of agreements aimed at eliminating or restricting competition by regulating pricing policy. For instance, the Code of Professional Ethics of Notaries Public of 1997 obligated the notaries to treat the maximum rates of the notarial fee as fixed prices and what's more, it prohibited 'tempting' the clients by offering them lower prices for the notarial services. In addition, in the Code of Professional Ethics of Pharmacists there was a provision prohibiting 'creating by patients a mistaken impression regarding the amount of the fee due for the medicines and medical materials, in particular by resigning from collecting the amount determined according to the law'.

Another example referring to the operations of professional self-government influencing the competition were provisions of the Code of Professional Ethics of Bailiffs which imposed on its members an obligation to 'refrain from a direct or indirect influence on a choice of a bailiff made by creditors and from soliciting the creditors in a way other than increasing effectiveness, tempo and reliability of the exercised enforcement proceedings' what included also refraining from lowering collection costs, conducting enforcement proceedings without prior call and collecting advance payments from creditors or calling to and collecting 
the advance payments in the amount insufficient to cover the cash expenses necessary for execution of the motions for enforcement proceeding. Violation of those obligations exposed the bailiff to disciplinary sanctions. The President recognized that the provisions restricted competition because they directly eliminated possibility of competing of bailiffs on lower costs, the amount of advance payment or resignation from its collection (Decision RKT-04/2014).

In addition to directly formulated rules and obligations, the authorities of professional self-government can adopt resolutions introducing recommendations regarding the applied prices. For instance, the Medical and Veterinary Chamber in Wielkopolska (region of Poland), Poznań on February 9, 1994 determined a specimen of optimal fees due for veterinary services as a basis for veterinary entities used during determining prices or services provided by them and published in an information bulletin a Proposal of a price list for veterinary services. Although the above mentioned documents did not include direct phrases and were only recommendations, due to the compulsory character of the membership and obligation of complying with the resolutions of the professional self-government, they could have had influence on shaping price competition on the veterinary services market.

Activities of professional self-government may also restrict the competition in public procurement proceedings by way of indirect impact on the methodology regarding preparation of the tender. The literature remarks that such influence shall have the resolutions of the professional self-governments authorities which prevent or restrict the members from the possibility of participating in the tender proceedings and influence a price or other conditions applied by their members in the tender proceedings (Materna 2014, pp. 15-21). As an example may serve the Act of the National Council of Notaries Public which prohibits notaries public from participating in tender proceedings or contests relating to notarial services. A further example is a resolution of the Code of Professional Ethics of Architects which prohibits the architects from taking part in contest and design works in which the only criterion is the price (Case XVII Ama 125/06, Case VI Aca 92/08). Even if determination of such a price is only a non-binding recommendation and violation of this recommendation is not threatened with a disciplinary liability, it would also restrict the competition because it allows all the market participants to forecast with high probability what will be the price policy of the competitors.

Although the above presented argumentation sounds convincing, there are some differences in its application between jurisprudence of the President and the Court. As an example may serve the evaluation of the provisions of professional self-government act of town-planners regarding adoption of rules referred to estimation of prices for town-planning works. The above mentioned provisions state that 'offering and accepting town-planning works for a price lower than the value of the contract (...) carrying a risk of improper performance of the documentation shall be deemed as violation of principles of professional ethics'. What is more, the provisions determine that offering town-planning 
works for a price $25 \%$ lower than the price of competitors is an unfair competition act what pursuant to professional conduct may be subject to disciplinary proceeding. While evaluating compliance of these provisions with Art. 6.1(1) of the Competition Act (2007), the President indicated that these provisions restrict the competition on the national market of the town-planning services by estimating prices for the selling prices of services (Decision RKT-22/2015). In the appeal proceeding, the Court claimed that such regulations do not lead to direct estimation of prices and do not restrict the prices policy. In its justification, the Court pointed out that principles of professional ethics of the town-planners did not impose on the town-planners any obligation regarding application of the indicated rules while estimating prices for town-planning works. Moreover, the Court agreed with the President that obligation regarding application of fixed prices for a work unit and obligatory use of basic units for workload did have influence on the price calculation (Case XVII Ama 127/13).

Relatively less frequently the authorities of professional self-government took steps aimed at restriction of competition by an access to the market. As examples may serve resolutions of pharmaceutical chambers or a resolution of the National Chamber of Notaries Public. The first one determines detailed criteria which are taken into consideration in the course of evaluating applications for granting a license, such as: number of residents attributable to the new pharmacy and the distance of such a pharmacy from another, already existing one. The latter restricts operation of more than one notary public's office in one building.

\subsection{Control and supervision over professional self-government}

Activities of professional self-governments are subject to control and supervision of government administration bodies and control of common and administration courts. While evaluating the supervision over professional self-government, it shall be pointed out that it is an aggregate of legal relations which the administration bodies establish with entities functioning within the centralized administration. Purpose of these legal relations is preventing risks for the public interest and eliminating consequences of violation of those interests (Szewczyk 1996, pp. 31-46). The basic criterion for such verification supervision shall be above all compliance with law but there are also other possible criteria indicated in literature.

With reference to the normative acts of the authorities of professional self-government, the litigator forecasted a particular control procedure. This procedure comprises an obligation of an authority to send to the supervision authority an extract of every adopted resolution and the supervision authority is entitled to apply to the Supreme Court or to the Voivodship Administrative Court for reversal of resolutions of professional self-governments authorities which are contrary to the law (Rączka 2013, p. 381). 
Regardless of the supervision exercised by a competent minister, activities of a professional self-government are also subject to supervision of the President. In the court jurisprudence was pointed out that control over professional self-government exercised by a competent supervision authority does not apply to practices restricting competition and violating collective consumer interest because only the President is competent to exercise such a control (Case VI Aca 92/08). The decision of the President may be appealed to the Competition Court. Subject matter of the proceedings before the Competition Court is not a control of legality of the administrative decision as such but settlement of a dispute between an entrepreneur filing an appeal and the President regarding a qualification of appellant's certain behavior (Skoczny 2014, p. 1347).

Besides the national law, control over resolutions of professional self-government regarding their compliance with the European Union competition rules may be exercised by the Court of Justice. In particular, attention should be paid to the preliminary ruling which concerns the interpretation of Article 101 TFEU (2012) and processing the complaints against decisions of the Commission.

Institutional construction of such control and supervision over the authorities of professional self-governments is oriented to possibility of reversal of decisions contrary to the law. Taking into consideration that the supervision authority is not entitled to reverse such resolution and can only appeal against it to a competent court, such construction guarantees independence and autonomy in the area of exercising public duties which were assigned for realization to the self-government (Rączka 2013, p. 383). Control of legality of resolutions under the competition law is of a different character - in this case the President is entitled to order discontinuance of practices which restrict competition or collective consumer interests arising from an adopted resolution and professional self-government authority has a right to appeal against such a decision to a court.

\section{Conclusion}

Professional self-government controls proper practice of the profession in accordance with the public interest and for its protection. With reference to the legislation, such control is connected with exercising power under public law in three areas: access to the profession, establishment of standards of professional conduct and exercise of disciplinary jurisdiction. Due to a compulsory character of a professional self-government and granting its member monopoly for exercising certain professional operations, a natural feature of professional self-government actions is aiming to limit the access to a profession, taking steps in order to increase prices or protecting the market. In some cases, activities which actually lead to restriction of competition may be justified by protection of public interest. In some other cases, a verification surveillance is required in order to remove practices contrary to the competition law from legal trade. 
Self-government authorities are subject to competition rules, both under Article 101 TFEU (2012) and the Competition Act (2007). In jurisprudence of the Court of Justice a tendency of more restrictive application of a state action doctrine can be observed. Research of court and regulatory jurisprudence shows, that actions of professional self-government which restrict the competition exist, however they are relatively infrequently. They have generally the form of normative acts which, due to a compulsory character of a professional self-government, concern every person practicing a particular profession and failure to comply with those rules and bans may result in disciplinary sanctions.

The performed analysis demonstrates that control and surveillance over the acts of a professional self-government under the Polish law enable to remove from legal trade resolutions contrary to the law or restricting the competition. Competences of the Supreme Court or voivodship administrative courts complement with competences of the President and the Competition Court.

\section{References}

Decision of the President of the Office of Competition and Consumer Protection in Poland of 31 March 2014. Case RKT-04/2014.

Decision of the President of the Office of Competition and Consumer Protection in Poland of 31 December 2015. Case RKT-22/2015.

Judgement of the Appeal Court in Warsaw of 10 July 2008. Case VI Aca 92/08. Judgement of the Court of Justice of the European Union of 19 February 2002.

Wouters v Algemene Raad van de Nederlandse Orde van Advocaten. Case C-309/99 (ECLI:EU:C:2002:98).

Judgement of the Court of Justice of the European Union of 12 September 2000. Pavlov v Stichting Pensioenfonds Medische Specialisten. Joined cases C-180/98 to C-184/98 (ECLI:EU:C:2000:428).

Judgement of the Court of Justice of the European Union of 23 April 1991. Höfner v Macrotron GmbH. Case C-41/90 (ECLI:EU:C:1991:161).

Judgement of the Court of Justice of the European Union of 18 July 2013. Consiglio nazionale dei geologi. Case C-136/12 (ECLI:EU:C:2013:489).

Judgement of the Court of Justice of the European Union of 28 February 2013. Ordem dos Técnicos Oficiais de Contas v Autoridade da Concorrência. Case C-1/12 (ECLI:EU:C:2013:127).

Judgement of the General Court of the European Union of 10 December 2014. Orde national des pharmaciens v European Comission. Case T-90/11 (ECLI:EU:T:2014:1049).

Judgment of the Court for the Protection of Competition and Consumer of 18 September 2007. Case XVII Ama 125/06.

Judgment of the Court for the Protection of Competition and Consumer of 13 October 2014. Case XVII Ama 127/13. 
Konstytucja RP z dnia 2 kwietnia 1997 r. [Constitution of the Republic of Poland of April 2, 1997] (Dz.U. 1997 nr 78 poz. 483) (Poland).

Kowalik-Bańczyk, K. (2009). State action defence a odpowiedzialność przedsiębiorcy za naruszenie art. 81 lub art. 82 TWE. Europejski Przegląd Sądowy, 6.

Materna, G. (2009). Pojęcie przedsiębiorcy w polskim i europejskim prawie ochrony konkurencji. Warszawa: Wolters Kluwer.

Materna, G. (2014). Uchwały i inne akty związków przedsiębiorców jako źródło ograniczenia konkurencji w postępowaniach o zamówienie publiczne. Przegląd Ustawodawstwa Gospodarczego, 7.

Rączka, K. (2013). Dziatalność prawodawcza samorządów zawodowych w Polsce. Toruń: TNOiK.

Tabernacka, M. (2007). Zakres wykonywania zadań publicznych przez organy samorzadu zawodowego. Wrocław: Kolonia Limited.

Skoczny, T. (Ed.). (2014). Ustawa o ochronie konkurencji i konsumentów. Warsaw: C.H. Beck.

Smith, A. (1776). An inquiry into the nature and causes of the wealth of nations. Retrieved 24.06.2018 from: http://www.econlib.org.

Szewczyk, M. (1996). Nadzór w materialnym prawie administracyjnym. Poznań: UAM.

Treaty on European Union (OJ C 326, 26.10.2012).

Treaty on the Functioning on the European Union (OJ C 326, 26.10.2012).

Ustawa z dnia 16 lutego 2007 r. o ochronie konkurencji i konsumentów [Competition and Consumer Protection Act of February 16, 2007] (Dz.U. 2007 nr 50 poz. 331) (Poland).

Ustawa z dnia 2 lipca 2004 r. o swobodzie działalności gospodarczej [Freedom of Business Activity Act of July 2, 2004) (Dz.U. 2004 nr 173 poz. 1807) (Poland).

\section{Acknowledgements}

Author contributions: author has given an approval to the final version of the article.

Funding: this research was fully funded by the National Science Centre, Poland under the grant (DEC-2011/01/D/HS5/01507). 
